\title{
Ascorbic Acid and Citric Flavonoids for Broilers Under Heat Stress: Effects on Performance and Meat Quality
}

\section{author(s)}

Peña JEM ${ }^{1}$

Vieira $S L^{1}$

López $J^{1}$

Reis RN ${ }^{1}$

Barros $\mathrm{R}^{1}$

Furtado FVF

Silva PX

Departamento de Zootecnia, Universidade Federal do Rio Grande do Sul. Porto Alegre, RS, Brasil.

\section{Mail Address}

JEM Peña

Departamento de Zootecnia, Universidade Federal do Rio Grande do Sul

Av. Bento Gonçalves, 7712

91.540-000. Porto Alegre, RS, Brasil.

E-mail: pena.jaime.1077@gmail.com

\section{Keywords}

Ascorbic acid, broiler, heat stress, flavonoids.

\section{Acknowledgements}

The authors thank the company Quinabra for funding and for supplying the commercial product; the Center for Meat Education, Research and Technology (Centro de Ensino, Pesquisa e Tecnologia de (arnes - (EPETEC), UFRGS; and the Center of Meat Technology (Centro de Tecnologia de Carnes - CTC) of Instituto de Tecnologia de Alimentos (ITAL). SP, for their help in meat quality analysis and interpretation of the results.

\section{ABSTRACT}

The aim of this study was to evaluate the effects of increasing doses of ascorbic acid (AA) and citric flavonoids (quercetin and rutin) on the performance and meat quality characteristics of broilers submitted to cyclic heat stress. Four-hundred one-day-old female Ross 308 were housed in 40 battery cages a in temperature controlled room. Treatments consisted of $0,250,500$, and $1000 \mathrm{~g} /$ ton on of AA + citric flavonoids. Birds were fed ad libitum until 32 day of age. Beginning on day 14 posthatch until the end of the experiment, in order to simulate cyclic heat stress, the temperature inside the room was increased to $32^{\circ} \mathrm{C}$ for 5 hours, and decreased until reaching the comfort temperature corresponding to the age of the animals. Birds were slaughtered at 33 days of age, and carcass and commercial cuts yields were determined. Thighs and boneless breast samples were collected and frozen for subsequent analyses of $\mathrm{pH}$, cooking loss, shear force, color, and Thiobarbituric Acid Reactive Substances (TBARS). Significant differences $(p<0.05)$ were found for feed efficiency from 1 to 7 days of age, with the best values for the birds fed 0 and $250 \mathrm{~g} /$ ton on of $A A+$ citric flavonoids. At the end of the experiment, there were no differences in other performance variables, carcass and parts yields, $\mathrm{pH}$, shear force, color and TBARS. The meat of the birds supplemented with $250 \mathrm{~g} / \mathrm{ton}$ on of product presented the lowest cooking loss.

\section{INTRODUCTION}

Poultry production in tropical countries is affected by the combined effects of high environmental temperature and humidity during most month of the year. As the ratio between humidity and environmental temperature exceeds the thermal comfort zone, birds become more susceptible to heat stress, which negatively influences performance and the efficiency of the immune system (Thaxton \& Siegel, 1970; Borges et al., 2003).

During stress, body and immune system cells undergo enzymatic or self-oxidative peroxidation through actions that involve free radicals, oxygen-reactive species, resulting in destabilization of the cell wall, and consequently, cell function loss (Puthpongsiripom et al., 2001). Excessive levels of free radicals may lead to lipid peroxidation, leading to several pathologies in the animals, and affecting meat organoleptic characteristics (Silva et al., 2002; Fellenberg \& Speisky, 2006).

The use of several dietary alternatives has been recommended to alleviate of high environmental temperature impact, such as changes in feeding and drinking water management. In addition, dietary nutritional changes, including replacing carbohydrates by lipids or reducing crude protein level, and the use of salts and additives in the drinking water have shown positive effects (Dale \& Fuller, 1978; Mendes et al., 1997; Borges et al., 2003). 
Peña JEM, Vieira SL, López J, Reis RN, Barros R, Furtado FVF, Silva PX
Ascorbic Acid and Citric Flavonoids for Broilers Under Heat Stress: Effects on Performance and Meat Quality
The use of traditional antioxidants, such as ascorbic acid (AA) has been recommended, and, in some cases, has presented promising effects in the attenuation of heat stress on performance (Stilborn et al., 1988). Alternatively, some compounds with antioxidant activity, such as flavonoids, may also be beneficial. Flavonoids (quercetin and rutin) are obtained by the fermentation of citrus, and polyphenolic substances widely distributed in plants. Many biological effects have been attributed to flavonoids as they may act as antioxidants in the liver and protector of blood vessels (Silva et al., 2002; Tieppo, 2007). According to Bianchi \& Antunes (1999), the combined use of antioxidants can reduce the effects of stress due to its oxi-reduction properties, which may have an important role in free radical quenching and neutralization, in addition to improving meat organoleptci characteristics and quality (Peterson \& Dwyer, 1998).

The present study aimed at evaluating the effect of increasing $A A$ and citric flavonoid doses on live performance and meat quality traits of broilers submitted to cyclic heat stress.

\section{MATERIAL AND METHODS}

A total number of 400 female Ross 308 broilers ( $44 \pm$ $0.5 \mathrm{~g}$ ) were used. Birds were distributed in randomized block design, with four treatments of 10 replicates of 10 birds each. The experiment was carried out in a temperature-controlled room. Birds were housed in metal cages $(0.80 \mathrm{~m} \times 0.90 \mathrm{~m})$ equipped with a feeder and a drinker each. Mash feeds were formulated with corn and soybean meal according to the recommendations of Rostagno et al. (2005), and are shown in Table 1. Treatments consisted of diets containing graded levels of AA and citric flavonoids, as presented in Table 2. The commercial product Biocitro ${ }^{\circledR}$ (Quinabra, São José dos Campos, Brazil), obtained by citrus fermentation, was used. It contains $10.0 \%$ AA and $0.7 \%$ flavonoids (50\% quercetin and $50 \%$ rutin). The feeding program was divided in two phases: starter, fed from 1 to 20 days, and grower, fed from 21 to 32 days.

Performance was weekly assessed, measuring body weight, feed intake, feed conversion ratio, and mortality. Initial room temperature was $32^{\circ} \mathrm{C}$, which was then daily adjusted until $25^{\circ} \mathrm{C}$ at 13 days of age. From day 14 until the end of the experimental period, room temperature simulated cyclic heat stress: it remained $32^{\circ} \mathrm{C}$ for 5 hours, and then was slowly reduced $\left(1^{\circ} \mathrm{C}\right.$ every $\left.12 \mathrm{~min}\right)$ until reaching the comfort temperature that corresponded to bird age.
Broilers were slaughtered at $33 \mathrm{~d}$ of age after 8 hours of fasting. Carcasses were chilled according the official regulations (Regulamento Técnico de Inspeção Tecnológica e Higiênico Sanitária de Carne de Aves; Brasil, 1998). Carcasses were then processed, and the following cuts were produced: deboned breast meat, breast fillet, thighs, legs, wings, and back. Breast and thighs were individually packaged in gas-impermeable plastic film (BB300-Cryovac ${ }^{\circledR}$ ), and stored in a freezer at $-18^{\circ} \mathrm{C}$ for 230 days. All cuts were individually weighed and expressed relative to empty carcass weight.

\begin{tabular}{|c|c|c|}
\hline \multicolumn{3}{|c|}{$\begin{array}{l}\text { Table } 1 \text { - Composition of the starter (1-20 days) and growe } \\
(21-32 \text { days } \% \text {. }\end{array}$} \\
\hline Ingredients & Initial & Grower \\
\hline Corn & 57.32 & 59.25 \\
\hline Soybean meal & 36.35 & 32.80 \\
\hline Soybean oil & 2.37 & 4.38 \\
\hline Calcitic limestone & 0.90 & 0.83 \\
\hline Dicalcium phosphate & 1.75 & 1.61 \\
\hline Salt & 0.34 & 0.35 \\
\hline Sodium bicarbonate $99 \%$ & 0.09 & 0.00 \\
\hline Biolys $50.7 \%$ Lys & 0.32 & 0.26 \\
\hline DL-Methionine $99 \%$ & 0.27 & 0.23 \\
\hline L-Threonine & 0.07 & 0.05 \\
\hline Choline chloride, liq. & 0.05 & 0.06 \\
\hline Mineral Premix Broiler & 0.05 & 0.05 \\
\hline Vitamin Premix Broiler & 0.12 & 0.12 \\
\hline TOTAL & 100.00 & 100.00 \\
\hline \multicolumn{3}{|c|}{ Nutritional levels, $\%$ or as described } \\
\hline AMEn, $\mathrm{kcal} / \mathrm{kg}$ & 3.000 & 3.150 \\
\hline Crude protein, \% & 21.6 & 20.0 \\
\hline Lys dig, \% & 1.20 & 1.08 \\
\hline Met+Cys dig, \% & 0.85 & 0.78 \\
\hline Thr dig, \% & 0.78 & 0.71 \\
\hline Val dig, \% & 0.90 & 0.84 \\
\hline $\mathrm{Ca}, \%$ & 0.90 & 0.83 \\
\hline$P$ disp, \% & 0.44 & 0.41 \\
\hline $\mathrm{Na}, \%$ & 0.18 & 0.16 \\
\hline $\mathrm{Cl}, \%$ & 0.30 & 0.30 \\
\hline$K, \%$ & 0.90 & 0.84 \\
\hline $\mathrm{BED}, \mathrm{mEq} / \mathrm{kg}$ & 224 & 200 \\
\hline Cholin, mg/kg & 1.600 & 1.600 \\
\hline
\end{tabular}

Enrichment per kg product: Vit A: 10,000,000 IU; Vit D3: 3,000,000 IU; Vit E: 40,000 IU; Vit K3: 3,000 mg; Vit B1: 2,000 mg; Vit B2: 6,000 mg; Vit B6: 4,000 mg; Vit B12: 20,000 mg; Nicotinic acid: 40,000 mg; Pantothenic acid: 12,000 mg; Folic acid: 1,000 mg; Biotin: $150 \mathrm{mg}$; Selenium: 250 mg; Fe: 60,000 mg; Cu: 10,000 mg; Zn: 100,000 mg; Mn: $100,000 \mathrm{mg}$; l: $1,000 \mathrm{mg}$.

Breast meat $\mathrm{pH}$, cooking loss (Chrystall et al., 1994), and shearing force (Liu et al., 2004) were determined. Meat color was measured in the center of the Pectoralis major (internal face) using a MINOLTA Chroma Meter CM 508-d spectrometer. $L^{*}$, $a^{*}$, and $b^{*}$ parameters were read according to the ICE (International Commission on Illumination) system. Thigh samples were submitted to TBARS assessment (Tarlagdis et al., 1960). 


\begin{tabular}{|c|c|c|c|c|}
\hline Treatment & Commercial product ${ }^{1}$ & Active principle concentration & AA & Quercetin 50\% Rutin 50\% \\
\hline Negative control & 0 & 0 & 0 & 0 \\
\hline T1 & 250 & 87.5 & 8.75 & 0.61 \\
\hline T2 & 500 & 175 & 17.50 & 1.22 \\
\hline T3 & 1000 & 350 & 35.00 & 2.45 \\
\hline
\end{tabular}

1 - Biocitro ${ }^{\circledR}$, commercial product obtained by the fermentation of citric fruits; contains $10.0 \%$ AA and $0.7 \%$ flavonoids.

Data were submitted to analysis of variance and regression using SAS (2001) package, and means that presented statistical difference were compared by the test of Tukey at $5 \%$.

\section{RESULTS AND DISCUSSION}

Live performance: No treatment effect was detected on body weight, feed intake, or mortality $(p \geq 0.05)$ (Table 3). General mortality was high, above the values commonly found under commercial production conditions. In the absence of health problems, this was probably consequence of the heat stress imposed to birds in all treatments.

\begin{tabular}{|c|c|c|c|c|}
\hline Treatments $\mathrm{g} /$ tonon & BW $^{1}$ & WG $^{2}$ & $\mathrm{Fl}^{3}$ & $M^{4}$ \\
\hline 0 & 1640 & 1597 & 2462 & 17.0 \\
\hline 250 & 1620 & 1576 & 2443 & 17.0 \\
\hline 500 & 1629 & 1584 & 2467 & 13.0 \\
\hline 1000 & 1606 & 1561 & 2451 & 10.0 \\
\hline$C V, \%$ & 3.6 & 3.7 & 3.4 & 48.3 \\
\hline PROB & $>0.601$ & $>0.590$ & $>0.913$ & $>0.826$ \\
\hline
\end{tabular}

$1-Y=1.64+(-0.00003) X ; p<0.0001 ; R^{2}=0.04 ; 2-Y=1.53+(-0.00003) X$ $\mathrm{p}<0.0001 ; \mathrm{R}^{2}=0.043 ; 3-Y=2.45+(-0.000004) X ; \mathrm{p}<0.0001 ; \mathrm{R}^{2}=0.0004$; $4-Y=17.60+(-0.0076) X ; p<0.0001 ; R^{2}=0.029$.

Feed conversion ratio was statistically different (pd< 0.001) for the period of 1 to 7 days of age, with broilers fed 0 and $250 \mathrm{~g} /$ ton Biocitro ${ }^{\circledR}$ presenting better feed conversion ratio as compared to those fed 500 and $1000 \mathrm{~g} /$ ton (Table 4).

The lack of treatment effects maybe related to the difficulty to determine the degree of stress to which the birds are experimentally submitted (Mckee \& Harrison, 1995; Whitehead et al., 2003). Puron \& Santamaria (1994) did not observe differences in weight gain, feed intake, feed conversion ratio or mortality of broilers fed 200 ppm AA, and attributed these results to the temperatures and times applied $\left(35-38^{\circ} \mathrm{C}\right.$ for 4 hours and $26-34^{\circ} \mathrm{C}$ for 6 hours, respectively), as the beneficial effects of $A A$ and flavonoids supplementation are most likely to be observed at higher temperatures. However, cyclic heat stress temperatures and times used in the study of Sahin et al. (2003) were higher $\left(34^{\circ} \mathrm{C}\right.$ for 8 $\mathrm{h} / \mathrm{d}$ ), and resulted in lower feed intake and worse feed conversion ratio in quails fed a diet supplemented with $250 \mathrm{mg}$ L-AA.

Consistent with Vathana et al. (2002), favorable temperatures and light provided for the entire 24-h day period may explain the lack of differences in body weight, weight gain, and feed intake among the experimental birds. Birds may have also suffered changes during the acclimation process, and therefore, did not suffer heat stress (Arjona et al., 1988).

AA supplementation showed positive effects on the reduction of corticosterone plasma levels ando $n$ the heterophil/lymphocyte ratio, as evaluated by Mckee \& Harrison (1995) in birds submitted to heat stress $\left(33^{\circ}\right.$ C) and supplemented with 150 and 300 ppm AA in the diet.

Meat yield and meat quality traits: No statistical differences were detected among the analyzed treatments for carcass and cut yields of 33-day-old birds $(p \geq 0.05)$ (Table 5).

\begin{tabular}{|c|c|c|c|c|c|c|c|}
\hline Treatments $\mathrm{g} /$ ton & $1-7^{1}$ & $7-14^{2}$ & $14-20^{3}$ & $1-20^{4}$ & $20-28^{5}$ & $28-32^{6}$ & $1-32^{7}$ \\
\hline 0 & $1.12^{a}$ & 1.33 & 1.45 & 1.35 & 1.72 & 1.71 & 1.54 \\
\hline 250 & $1.14^{a}$ & 1.31 & 1.45 & 1.35 & 1.76 & 1.69 & 1.55 \\
\hline 500 & $1.15^{b}$ & 1.32 & 1.47 & 1.36 & 1.74 & 1.74 & 1.56 \\
\hline 1000 & $1.21^{b}$ & 1.31 & 1.46 & 1.36 & 1.80 & 1.71 & 1.57 \\
\hline$C V, \%$ & 4.3 & 3.2 & 2.3 & 1.5 & 8.5 & 5.3 & 2.4 \\
\hline PROB & d 0.001 & $>0.614$ & $>0.426$ & $>0.527$ & $>0.644$ & $>0.673$ & $>0.364$ \\
\hline
\end{tabular}

Means followed by different letters in the same column are different by the test of Tukey at $5 \%$ significance. Columns in bold correspond to heatstress days. $1-Y=1.12+0.00009 X ; p<0.0001 ; R^{2}=0.37 ; 2-Y=1.32+(-0.00001) X ; p<0.0001 ; R^{2}=0.36 ; 3-Y=1.45+0.00009 X ; p<0.0001 ; R^{2}=0.11 ; 4-$ $Y=1.35+0.00001 X ; p<0.0001 ; R^{2}=0.049 ; 5-Y=1.72+0.00007 X ; p<0.0001 ; R^{2}=0.036 ; 6-Y=1.71+0.000005 X ; p<0.0001 ; R^{2}=0.0005 ; 7-$ $Y=1.54+0.00003 X ; \mathrm{p}<0.0001 ; \mathrm{R}^{2}=0.079$. 


\begin{tabular}{|c|c|c|c|c|c|c|c|c|}
\hline Treatments $\mathrm{g} /$ ton & Carcass $^{1}$ & Abdominal fat ${ }^{2}$ & Back $^{3}$ & Breast $^{4}$ & Breast fillet $^{5}$ & Thigh $^{6}$ & Drumstick $^{7}$ & Wing $^{8}$ \\
\hline 0 & 77.10 & 1.62 & 23.60 & 24.60 & 4.87 & 12.98 & 19.31 & 11.97 \\
\hline 250 & 76.60 & 1.56 & 23.60 & 24.40 & 4.87 & 13.24 & 19.01 & 11.89 \\
\hline 500 & 77.30 & 1.70 & 23.60 & 24.10 & 4.89 & 12.92 & 18.99 & 11.98 \\
\hline 1000 & 77.20 & 1.61 & 23.40 & 24.20 & 5.43 & 12.93 & 19.06 & 12.06 \\
\hline CV \% & 1.9 & 11.1 & 2.4 & 2.4 & 17.7 & 2.4 & 2.9 & 2.7 \\
\hline PROB & $>0.702$ & $>0.345$ & $>0.856$ & $>0.296$ & $>0.422$ & $>0.087$ & $>0.554$ & $>0.727$ \\
\hline
\end{tabular}

$1-Y=76.94+0.0003 X ; p<0.0001 ; R^{2}=0.007 ; 2-Y=1.61+0.00002 X ; p<0.0001 ; R^{2}=0.0022 ; 3-Y=23.62+(-0.00014) X ; p<0.0001 ; R^{2}=0.009 ; 4-$ $Y=24.44+(-0.0003) X ; \mathrm{p}<0.0001 ; \mathrm{R}^{2}=0.039 ; 5-Y=4.76+0.00057 X ; \mathrm{p}<0.0001 ; \quad \mathrm{R}^{2}=0.06 ; 6-Y=13.07+(-0.00014) X ; \mathrm{p}<0.0001 ; \mathrm{R}^{2}=0.0298 ; 7-$ $Y=19.18+(-0.00019) X ; \mathrm{p}<0.0001 ; R^{2}=0.017 . ; 8-Y=11.92+0.00011 X ; \mathrm{p}<0.0001 ; R^{2}=0.019$.

The use of body energy reserves during heat stress periods may vary with dietary carbohydrate and fat levels or with AA dietary supplementation, as well as with corticosteroid synthesis and the production of thyroid hormones (Dale \& Fuller, 1980; Mckee et al., 1997). Although plasma hormone concentrations were not measured in the present study, these probably were not significant as no differences in abdominal fat yield were detected ( $p>0.05$ ).

Data presented in Table 6 showed that the experimental treatments did not cause any significant differences in breast $\mathrm{pH}$ at the different measurement times. However, $\mathrm{pH}$ tended to decline as a function of time. After rigor mortis resolution (4 h post-mortem), breast meat $\mathrm{pH}$ is commonly between 5.7 and 5.9, and must remained unchanged after this time. A slight increase is expected after long storage times due to the formation of basic substances (Souza, 2006). As $\mathrm{pH}$ was not measured $24 \mathrm{~h}$ post-mortem, it was not possible to establish if values were lower than those obtained at $4 \mathrm{~h}$. considering that these values were close to those recorded at that time, meat probably presented normal behavior and that birds were not sufficiently stressed to present meat changes, such as those observed in PSE or DFD pork, present in poultry meat with $\mathrm{pH}$ higher than 6.2 at $24 \mathrm{~h}$ post mortem or below 5.7 during the first 45 min after slaughter (Aks'it et al., 2006).

\begin{tabular}{|c|c|c|c|}
\hline \multicolumn{4}{|c|}{$\begin{array}{l}\text { Table } 6 \text { - Mean pH values of the breast meat of female broilers } \\
\text { fed diets supplemented with different concentrations of } A A+ \\
\text { citric flavonoids. }\end{array}$} \\
\hline Treatments $\mathrm{g} /$ ton & $1 h^{1}$ & $4 h^{2}$ & Final*3 \\
\hline 0 & 6.27 & 5.97 & 5.95 \\
\hline 250 & 6.44 & 5.93 & 5.90 \\
\hline 500 & 6.30 & 5.88 & 5.88 \\
\hline 1000 & 6.37 & 6.10 & 5.94 \\
\hline CV \% & 4.0 & 3.1 & 1.3 \\
\hline PROB & $>0.454$ & $>0.108$ & $>0.200$ \\
\hline
\end{tabular}

Nevertheless, as shown in Table 7, there were significant differences in cooking loss of thawed weight loss both in grams and in percentage $(\mathrm{pd} \leq 0.037$ and $\mathrm{pd} \leq 0.020$, respectively), with the treatment $1000 \mathrm{~g} /$ ton promoting the highest loss.

\begin{tabular}{|c|c|c|c|c|c|}
\hline $\begin{array}{l}\text { Treatments } \\
\text { g/ton }\end{array}$ & $\begin{array}{c}\text { TWL }^{\mathrm{A} 1}, \\
\%\end{array}$ & $\begin{array}{c}\operatorname{ThWL}^{\mathrm{B2}} \text {, } \\
\mathbf{g}\end{array}$ & $\begin{array}{c}\mathrm{CW}^{\mathrm{c}}, \\
\mathrm{g}\end{array}$ & $\begin{array}{c}\mathrm{CWL}^{\mathrm{D} 4}, \\
\%\end{array}$ & $\begin{array}{c}\text { CkWL }{ }^{\text {E5 }} \text {, } \\
\text { g }\end{array}$ \\
\hline 0 & $41^{\mathrm{ab}}$ & $13^{b}$ & 221 & 61 & 22 \\
\hline 250 & $38^{b}$ & $12^{\mathrm{b}}$ & 217 & 53 & 19 \\
\hline 500 & $41^{a b}$ & $13^{b}$ & 217 & 57 & 21 \\
\hline 1000 & $52^{a}$ & $17^{a}$ & 199 & 58 & 22 \\
\hline CV \% & 24.1 & 22.2 & 8.6 & 19.4 & 16.3 \\
\hline PROB & $d^{2} 0.037$ & $d^{\prime} 0.020$ & $>0.066$ & $>0.399$ & $>0.297$ \\
\hline
\end{tabular}

Means followed by different letters in the same column are different by the test of Tukey at $5 \%$ significance. ${ }^{A T W L}=$ thawed weight loss; ${ }^{\mathrm{B}} \mathrm{ThWL}=$ thawed weight loss; ${ }^{\mathrm{C}} \mathrm{CW}=$ cooked weight; ${ }^{\mathrm{D}} \mathrm{CWL}=$ cooked weight loss; ${ }^{\mathrm{E}} \mathrm{CkWL}=$ cooked weight loss.1 $-Y=37.10+0.012 X$; $\mathrm{p}<0.0001 ; \mathrm{R}^{2}=0.143 ; 2-Y=11.66+0.0045 X ; \mathrm{p}<0.0001 ; \mathrm{R}^{2}=0.183 ; 3-$ $Y=222.95+(-0.021) X ; \mathrm{p}<0.0001 ; \mathrm{R}^{2}=0.1655 ; 4-Y=57.62+(-0.0009) X ;$ $\mathrm{p}<0.0001 ; \mathrm{R}^{2}=0.0009 ; 5-Y=20.48+0.0014 X ; \mathrm{p}<0.0001 ; \mathrm{R}^{2}=0.019$.

These results have no relation with $\mathrm{pH}$ values, as the $\mathrm{pH}$ highest value seems to indicate a slower decline, leading to higher water retention capacity. According to Souza (2006), breast meat cooking loss varies between 18 and 29\%, which is consistent with the results obtained in the present study.

No significant differences were observed in shear force $(p>0.05)$ (Table 8).

However, this parameter has no relation with the results obtained for cooking loss, as meat texture is closely linked to intramuscular water content (Lawrie, 2005). According to Souza (2006), breast meat shearing force values are approximately 2.50 to $5.00 \mathrm{kgf}$. The low values obtained in the present study could be related to the chemical and centesimal composition of the muscle, which changes with bird age and genetics (Olivo \& Olivo, 2005).

Data presented in Table 8 show that the experimental treatments did not result in significant 
differences for $L^{*}, a^{*}$, or $b^{*}$ values. Several authors relate meat color to $\mathrm{pH}$ and to water retention capacity (Yang \& Chen, 1993; Fletcher, 1995; Moreira, 2005; Olivo \& Olivo, 2005). According to Zapata et al. (2006), freezing seems to produce a marked darkening, reducing chicken mean luminosity. However, in the present study, results indicate that meat was normal with $L^{*}$ values between 44 and 53 , and a $\mathrm{pH}$ of 5.7 . The $a^{*}$ and $b^{*}$ color components indicate that the meat samples were dark red and yellowish, This was possibly due to partial cell breakdown and blood migration caused by the slow freezing process or to the oxidation of the meat pigment, which stability depends on animal species, muscle biochemical characteristics, and some external parameters (Lyon \& Lyon, 2002).

Table 8 - Mean Warner-Bratzler shear force (kgf), $L^{*}, a^{*}$, and $b^{*}$, and TBARS (mg malonaldehyde/kg sample) values of breast meat samples of female broilers fed diets supplemented with different concentrations of $A A+$ citric flavonoids.

\begin{tabular}{cccccc} 
Treatments $\mathbf{g} /$ ton & $\mathbf{F C}^{1}$ & $\mathbf{L}^{* 2}$ & $\mathbf{a}^{* 3}$ & $\mathbf{b}^{* 4}$ & TBARS $^{5}$ \\
0 & 1.25 & 45 & 3.40 & 8.30 & 1.47 \\
250 & 1.28 & 45 & 3.35 & 8.69 & 1.58 \\
500 & 1.61 & 46 & 3.31 & 8.52 & 1.06 \\
1000 & 1.40 & 47 & 3.21 & 8.63 & 1.68 \\
CV \% & 24.1 & 4.7 & 28.1 & 14.4 & 40.1 \\
PROB & $>0.090$ & $>0.223$ & $>0.971$ & $>0.905$ & $>0.125$ \\
\hline
\end{tabular}

$1-Y=1.30+0.0002 X ; p<0.0001 ; R^{2}=0.04 ; 2-Y=44.84+0.002 X ;$ $\mathrm{p}<0.0001 ; \mathrm{R}^{2}=0.119 ; 3-Y=3.40+(-0.00018) X ; \mathrm{p}<0.0001 ; \mathrm{R}^{2}=0.0068$; 4- $Y=8.43+0.0002 X_{i} p<0.0001 ; R^{2}=0.0051 ; 5-Y=1.39+0.00011 X_{i}$ $\mathrm{p}<0.0001 ; \mathrm{R}^{2}=0.0054$.

Table 8 shows mean TBARS levels of the frozen thigh meat samples. Samples of birds fed 250 and $1000 \mathrm{~g} /$ ton of the product presented the highest values, and those of treatments 0 and $500 \mathrm{~g} /$ ton had the lowest values. However, data analysis did not show any influence of treatments on this parameter.

\section{CONCLUSIONS}

The addition of graded $A A$ and citric flavonoids (quercitin and rutin) levels to the broiler diets did not affect live performance, commercial cut yield, carcass yield or meat quality trait parameters. However, differences were found in feed conversion ratio and thawed weight loss. The addition of graded levels of the product impaired feed conversion ratio of birds during the first week of age, and increased breast water loss of birds processed at 32 days of age.

\section{REFERENCES}

Aks'it M, Yalc'ýn S, O" zkan S, Metin K, O" zdemir D. Effects of temperature during rearing and crating on stress parameters and meat quality of broilers. Poultry Science 2006; 85:1867-1874

Arjona AA, Denbow DM, Weaver WD. Effect of heat stress early in life on mortality of broilers exposed to high temperature just prior to marketing. Poultry Science 1988; 67: 226-231.

Bianchi MLP, Antunes LMG. Free radicals and the main dietary antioxidants Revista. Nutrição 1999; 12(2):123-130

Borges AS, Maiorka A, Da Silva AV. Fisiologia do estresse calórico e a utilização de eletrólitos em frangos de corte. Ciência Rural 2003; 33(5):975-981

Brasil, Ministério de Agricultura Pecuária e do Abastecimento (MAPA). Secretaria da Defesa Agropecuária (SDA). Departamento de Inspeção de Produtos de Origem Animal (DIPOA). Divisão de Normas Técnicas. Portaria n. 210, de 10 de novembro de 1998. Aprova o Regulamento Técnico da Inspeção Higiênico Sanitária de Carne de Aves. Lex: Diário Oficial da União de 28 de novembro de 1998. Seção I. p.226. Republicado no diário Oficial da União de 5 de março de 1999, Seção I. p.17-22, por conter incorreções ortográficas e retificação nos anexos. Brasília; 1999

Chrystall B, Culioli J, Honikel KO, Möller AJ, Purslow P, Schwägele $F$, Shorthose R, Uytterhaegen $L$. Recommendation of reference methods for assesment of meat tenderness. Proceedings of the $40^{\text {th }}$ International Congress of Meat Science and Technology; 1994; The Hague, The Netherlands. Holanda. The Hague: ICo MST; 1994. p.1-7.

Dale NM, Fuller HL. Effect of ambient temperature and dietary fat of feed preference of broilers. Poultry Science 1978; 57:1635-1640

Dale NM, Fuller HL. Effect of diet composition on feed intake and growth of chicks under heat stress. II. Constant Vs cycling temperatures. Poultry Science 1980; 59:1434-1441

Fellenberg MA, Speisky H. Antioxidants: their effects on broiler oxidative stress and its meat oxidative stability. World's Poultry Science Journal 2006; 62:53-70

Fletcher DL. Relationship of breast meat color variation to muscle $\mathrm{pH}$ and texture. Poultry Science 1995; 74(Suppl 1):120

Lawrie RA. A qualidade sensorial da carne. In: Lawrie RA. Ciência da carne. 6. ed. Porto Alegre (RS): Artmed; 2005. p. 256-268

Liu Y. Principal component analysis of physical, color, and sensory characteristics of chicken breasts deboned at two, four, six, and twenty-four hours post-mortem. Poultry Science 2004; 83(1):101108

Lyon BG, Lyon CE. Color of uncooked and cooked broiler leg quarters associated with chilling temperature and holding time. Poultry Science 2002; 81(12):1916-1920

Mckee JS, Harrison PC. Effects of supplemental ascorbic acid on the 

Peña JEM, Vieira SL, López J, Reis
RN, Barros R, Furtado FVF, Silva PX
Ascorbic Acid and Citric Flavonoids for Broilers Under Heat Stress: Effects on Performance and Meat Quality performance of broiler chickens exposed to multiple concurrent stressors. Poultry Science 1995; 74(11):1772-1785

Mckee JS, Harrison PC, Riskowski RL. Effects of supplemental ascorbic acid on the energy conversion of broiler chicks during heat stress and feed withdrawal. Poultry Science 1997; 76; 12781286

Mendes AA, Watkins, England JA, Saleh EA, Waldroup AL, Waldroup LW. Influence of dietary lysine levels and arginine:lysine ratios on performance of broilers exposed to heat or cold stress during the period of three to six weeks of age. Poultry Science 1997; 76:472481.

Moreira J. Causas da ocorrência de carne PSE em frangos de corte e como controlá-las. Anais do $4^{\circ}$ Seminário Internacional de Aves e Suínos; 2005. Florianópolis, Santa Catarina. Brasil. Concórdia: Embrapa Suínos e Aves; 2005.

Olivo R, Olivo N. Atualidades na qualidade da carne de aves. In: Olivo R, Olivo N. O mundo das carnes, 2. ed. Criciúma (SC); 2005.

Peterson J, Dwyer J. Flavonoids: dietary occurrence and biochemical activity. Nutrition Research 1998; 18(12):1995-2018.

Puron D, Santamaria R. Effects of sodium bicarbonate, on broiler performance in a acetylsalicylic, and ascorbic acid tropical environment. Journal of Applied Poultry Research 1994; 3:141145.

Puthpongsiriporn U, Scheideler SE, Sell JL, Beck MM. Effects of vitamin $E$ and $C$ supplementation on performance, in vitro lymphocyte proliferation, and antioxidant status of laying hens during heat stress. Poultry Science 2001; 80:1190-1200.

Rostagno, H.S. Tabelas brasileiras para aves e suínos. 2.ed. Visoça (MG): Universidade Federal de Viçosa; 2005.

Sahin K, Onderci M, Sahin N, Gursu MF, Kucuk O. Dietary vitamin C and folic acid supplementation ameliorates the detrimental effects of heat stress in japanese quail. Journal of Nutrition 2003; 133:18821886.

SAS Institute. SAS user's guide: Statistics, Version 8.0 Edition. Cary (NC); 2001

Silva RR, Oliveira TT, Nagem TJ, Leão MA. Effect of flavonoids on the arachidonic acid metabolism. Medicina - Ribeirão Preto 2002; 35:127-133.

Souza HBA. Parâmetros físicos e sensoriais utilizados para avaliação de qualidade da carne de frango. Anais do Seminário Internacional de Aves e Suínos; 2005. Florianópolis, Santa Catarina. Brasil. Concórdia: Embrapa Suínos e Aves; 2005.

Stilborn HL, Harris GS, Pottje WG, Waldroup PW. Ascorbic acid and acetilicylic acid (aspirin) in the diets for broilers maintained under heat stress conditions. Poultry Science 1988; 67(8):1183-1187.

Tarlagdis BG, Watts BM, Younathan MT. A destillation methodology for the quantitation, determination of malonaldeide in rancid foods. The Journal of American Oil Chemist's Society 1960; 37:44-48.
Thaxton JP, Siegel HS. Immunodepression in young chickens by high environmental temperature. Poultry Science 1970; 49(1):202205.

Tieppo J, Vercelino R, Dias AS, Silva Vaz MS, Silveira TR, Marroni CA, Marroni NP, Henriques JAP, Picada JN. Evaluation of the protective effects of quercetin in the hepatopulmonary syndrome. Food and Chemical Toxicology 2007; 45:1140-1146.

Vathana S, Kang K, Loan CP, Thinggaard G, Kabasa JD, Ter meulen $U$. Effect of Vitamin C Supplementation on Performance of Broiler Chickens in Cambodia. Conference on International Agricultural Research for Developmen: Deutscher Tropentag; 2002; Witzenhausen. German.

Whitehead CC, Keller T. An update on ascorbic acid in poultry. World's Poultry Science Journal 2003; 59:161-184.

Yang CC, Chen TC. Effects of refrigerated storage, pH adjustment, and marinade on color of raw and microwave cooked chicken meat. Poultry Science 1993; 72:355-362.

Zapata JFF, De Andrade AA, Assunção GM, Barreto SCS, Abreu VKG. Preliminary evaluation of the effect of frozen storage on the quality of breast meat from two genetic groups of chickens. Brazilian Journal of Food Technology 2006; 9(3):185-191. 